\title{
Does Wolbachia infection affect Trichogramma atopovirilia behaviour?
}

\author{
Almeida, RP. de $e^{\mathrm{a} *}$, van Lenteren, $J C .^{\mathrm{b}}$ and Stouthamer, . $^{\mathrm{c}}$ \\ a'Centro Nacional de Pesquisa de Algodão, Empresa Brasileira de Pesquisa Agropecuária - EMBRAPA Algodão, \\ CP 174, Campina Grande, PB, Brazil \\ ${ }^{\mathrm{b}}$ Laboratory of Entomology, Wageningen University, \\ P.O. Box 8031, 6700EH Wageningen, The Netherlands \\ 'Department of Entomology, University of California, Riverside, CA 92521, USA \\ *e-mail: raul@cnpa.embrapa.br
}

Received February 9, 2009 - Accepted April 24, 2009 - Distributed May 31, 2010

(With 2 figures)

\begin{abstract}
Unisexual Trichogramma forms have attracted much attention due to their potential advantages as biocontrol agents. Fitness studies have been performed and understanding the cost that Wolbachia may inflict on their hosts will help in deciding if Wolbachia infected (unisexual) forms are indeed better than sexual forms when used in biological control programmes. The influence of Wolbachia on the foraging behaviour (including walking activity and speed) of $T$. atopovirilia is reported in this paper. Temperature strongly affected $T$. atopovirilia female walking activity, but Wolbachia infected and uninfected females differed in none of the behavioural components that were measured such as walking activity and walking speed. Walking activity was highest at $25{ }^{\circ} \mathrm{C}$ and differed significantly from that at 20 and $15{ }^{\circ} \mathrm{C}$. Trichogramma wasps were highly affected at $15{ }^{\circ} \mathrm{C}$. Behaviour analysis with females showed that female wasps spend most of the time on drilling + ovipositing on host eggs followed by host drumming and walking while drumming. The parasitism rate and number of offspring did not differ significantly between infected and cured Trichogramma females. Biological control implications of these findings are discussed.
\end{abstract}

Keywords: Hymenoptera, Parasitoid, thelytoky, alpha-Proteobacteria, foraging behaviour.

\section{A infecção por Wolbachia afeta o comportamento de Trichogramma atopovirilia?}

\section{Resumo}

Formas unissexuais de Trichogramma têm despertado a atenção de pesquisadores devido as potenciais vantagens deste parasitóide como agente de controle biológico. O estudo do "Fitness" tem sido avaliado e entender o custo de ser infectado por Wolbachia ajudará em determinar se formas infectadas por Wolbachia (unisexuais) são realmente melhores que as sexuadas quando utilizadas em programas de controle biológico. A influência de Wolbachia no comportamento de procura (incluindo a atividade e a velocidade de caminhamento) de T. atopovirilia é relatada neste artigo. A temperatura afetou grandemente a atividade de caminhamento de fêmeas de T. atopovirilia, entretanto os componentes de comportamento tais como a atividade e a velocidade de caminhamento não diferiram em relação às fêmeas infectadas e não infectadas. A atividade de caminhamento foi maior a $25^{\circ} \mathrm{C}$ e diferiu significativamente de 20 e $15^{\circ} \mathrm{C}$. Fêmeas de Trichogramma foram altamente afetados a $15^{\circ} \mathrm{C}$. Em função da análise do comportamento com fêmeas, pode-se verificar que houve maior tempo gasto no processo de oviposição, seguido pelo toque com as antenas sobre os ovos dos hospedeiros e do caminhamento ao mesmo tempo que toca os ovos com as antenas. A taxa de parasitismo e o número de descendentes não diferiram significativamente entre fêmeas de Trichogramma infectadas e curadas da infecção por Wolbachia. As implicações dos resultados obtidos sobre o controle biológico são discutidas.

Palavras-chave: Hymenoptera, Parasitóide, telitoquia, alpha-Proteobacteria, comportamento de procura.

\section{Introduction}

In biological control applications the proper selection of natural enemy strains and species is still an area of great concern. Although selection methods are available and various effective species have been identified, often they cannot be effectively used in biological control programmes because many species are difficult to mass rear (Lenteren, 2000). The importance of quality components for the production and use of Trichogramma wasps has 
been discussed by Bigler (1994). He identified the following major quality components: adaptability, habitat location, host location, host acceptance, host suitability, synchronisation with host, density dependent properties, intrinsic rate of increase, laboratory rearing properties and quarantine and handling properties. Selection of the appropriate Trichogramma population is based on interand intraspecific variation, as well as on current definitions of parasitoid quality (Smith, 1996).

The need of using adequate criteria to evaluate parasitoid quality before they are released is a pre-requisite for successful biocontrol. Quality control guidelines consist mainly of characteristics that are easy to determine in the laboratory (Lenteren, 2000). However, quality control should ensure good natural-enemy performance in the field (Lenteren, 1991). Good evaluation criteria allow for a choice between useless and potentially promising natural enemies (Lenteren and Manzaroli, 1999). Such a choice prevents the introduction of inefficient natural enemies. A list of criteria for pre-introductory evaluation of natural enemies includes seasonal synchronisation with host, internal synchronisation with host, climatic adaptation, no negative effects on other beneficial organism or non-target species, good rearing methods, host specificity, great reproductive potential, and good density responsiveness.

Recently Roitberg et al. (2001) has clarified the fitness concept by discussing its definition and the ways it can be measured. It should not be confused with vigour or quality, although these may be indirect measures of fitness. Parasitoid fitness may be measured for testing evolutionary theory or for assessing ecological applications such as biological control. Body size, progeny survival, development rate, longevity and fecundity are the most used measurements of fitness.

In Trichogramma species, parthenogenesis-inducing Wolbachia is known in ca. 9\% of the species. Wolbachia infection causes reproductive modifications and two types are found in Trichogramma:

1) Thelytoky (infected females with Wolbachia produce female offspring without mating and these bacteria are inherited through the cytoplasm of the eggs) (Stouthamer and Luck, 1993; Stouthamer et al., 1994); and

2)Fecundity increase (Wolbachia bacteria infection induces the increase of female wasps fecundity) (Girin and Boulétreau, 1995; Vavre et al., 1999).

In thelytoky, a physiological cost such as a reduced fecundity on Trichogramma hosts (Stouthamer and Luck, 1993) may be imposed because of the presence of a large number of Wolbachia bacteria inside host tissues (Stouthamer et al., 1999). Many cases of negative effects of Wolbachia infection on Trichogramma have been found (Stouthamer and Luck, 1993; Stouthamer et al., 1994; Horjus and Stouthamer, 1995; Hoogenboom et al., 1998; Silva et al., 2000; Tagami et al., 2002). However, positive (Girin and Bouletreau, 1995; Wade and Chang,
1995; Vavre et al., 1999) or neutral (Stouthamer et al., 1994) effects on fitness have also been reported.

Although a large number of traits have been studied to improve biological control strategies such as searching behaviour, dispersal, emergence rate of the parasitised eggs, percentage of non-deformed females, walking speed and walking activity (Burbutis et al., 1977; Kot, 1979; Greenberg, 1991; Kazmer and Luck, 1995; Cerutti and Bigler, 1995; Romeis et al., 1998; Drost et al., 2000; Suverkropp et al., 2001) few traits have been studied in Trichogramma species infected with Wolbachia. A single study (Silva et al., 2000) was done to test the biocontrol performance of Wolbachia infected versus cured wasps in a greenhouse setting. That study showed that the infected wasps appeared as good as uninfected wasps in finding host patches, but that once a host patch had been found, an infected female parasitised fewer eggs than uninfected females.

To better understand the way Trichogramma effectiveness might be influenced, the searching process needs to be studied. Examples of important parameters are: the walking activity parameter (defined as walking time divided by total time) and the walking speed (Suverkropp, 1994). Studying T. brassicae Bezdenko, 1968 Pompanon et al. (1994) found a walking activity of 0.8 for females during the light period at $22{ }^{\circ} \mathrm{C}$. Boldt (1974) using T. evanescens Westwood, 1833 observed that walking activity increased from $0.5-0.7$ at $20^{\circ} \mathrm{C}$ to 0.9 at $25{ }^{\circ} \mathrm{C}$. At temperatures above $25{ }^{\circ} \mathrm{C}$, the walking activity did not increase any further. Linear increase of the walking speed from 20 to $35^{\circ} \mathrm{C}$ was found by Biever (1972) in T. evanescens. At $40{ }^{\circ} \mathrm{C}$, the T. evanescens wasps died. Suverkropp et al. (2001) observed a significant effect of the temperature on T. brassicae walking speed. At $20^{\circ} \mathrm{C}$ the average walking speed was twice as high as at $12^{\circ} \mathrm{C}$. Considerable variation was found in $T$. brassicae between strains (Cerutti and Bigler, 1991).

Lenteren et al. (1980) studied the behaviour of the whitefly parasitoid Encarsia formosa Gahan, 1924 (host-searching, host-selection, host-discrimination and host-feeding) with several goals: to improve the massrearing of the parasitoid; to determine the moment of its introduction into the greenhouse; and to determine how the parasitoid locates its hosts. In a model of foraging behaviour, Roermund (1995) showed that aspects like the leaflet size, the parasitoid walking speed and walking activity and, to a lesser extent, width of the parasitoid searching path and diameter of the immature host are the most important parameters in determining the encounter rate of the parasitoid with its host. Also important for the success of the wasps were the probability of oviposition after encountering a host and the parameters determining the parasitoid searching time on the lower and upper leaf side. Using Trichogramma wasps, Pak (1988) studied similar traits as those studied in E. formosa to evaluate the female parasitoid behaviour. In our study we determine the influence of carrying a Wolbachia infection by 
T. atopovirilia on its walking activity, walking speed and several other behavioural components.

\section{Material and Methods}

\subsection{Culture and antibiotic treatment}

Trichogramma atopovirilia Oatman and Platner, 1983 Oatman and Platner (line Tato-01) was collected in Minas Gerais state, Brazil, on corn. Originally infected with Wolbachia (Ciociola et al., 2001), Trichogramma females were submitted to an antibiotic treatment, by mixing the honey that they use as a food source with $0.5 \% \mathrm{w} . \mathrm{v}^{-1}$ rifampicin. This treatment was continued for three generations. Cured parasitoids were reared for several generations after the treatment ended before they were used in experiments. Thus, we could be sure that the rifampicin residual effect would not affect the experimental results. Tests to verify that the Wolbachia infection was truly cured were performed:

1) Twenty virgin females were allowed to lay eggs for one day. If only male offspring emerge, the test indicates that the infection is not present, because under their normal mode of reproduction, i.e. arrhenotoky, males arise from unfertilised eggs and females from fertilised ones (Stouthamer et al., 1990); and

2) Testing for the presence of bacteria by doing PCR using Wolbachia specific primers (wsp) (Braig et al., 1998).

All behavioural experiments were done at 02:10 PM (L:D) and $75 \pm 10 \%$ R.H. using wasps that had been reared on Ephestia kuehniella Zeller eggs. The light phases started at 8:00 AM. All experiments were initiated with both infected and cured females that were 1 day old. To assure that the females were all of a similar size, we measured their hind tibia length (HTL) using an optical micrometer mounted on an eyepiece of a compound microscope.

\subsection{Walking activity}

This is defined as the fraction of females observed that were active at the moments of observation (Suverkropp et al., 2001) and was analysed at three temperatures $\left(15,20\right.$ and $\left.25^{\circ} \mathrm{C}\right)$. One day old infected and mated cured female $T$. atopovirilia wasps were placed into vials (75 $\mathrm{mm}$ long and $10 \mathrm{~mm}$ diameter) with a drop of honey and closed with cotton wool. The tubes with Trichogramma females were laid slightly inclined in the climate chambers. The experiment lasted for four days. The evaluation of each single individual was performed every 30 minutes from 08:30 AM to 06:00 PM with a total of 20 observations per day. During each observation the wasps were checked to determine if they were moving, standing still or dead. Forty replicates were used for both infected and cured female wasps. Walking activity calculation was done by dividing the number of observations where the wasps were active by the total number of observations. A completely random design was used in the data analysis. The data were submitted to two-factor analysis of variance and means compared by Tukey test $(\mathrm{P} \leq 0.05$ and $\mathrm{P} \leq 0.01)$.

\subsection{Walking speed}

Infected and cured females used for measuring the walking speed were one day old. To standardise the adult female size Trichogramma wasps were reared on E. kueniella. To determine if the size of the hind tibia length of infected and cured females were statistically different, we used a Student $T$-test $(\mathrm{P}=0.05)$. To measure the walking speed each female wasp was placed in an arena (plastic Petri dish $5.5 \mathrm{~cm}$ diameter) with wet cotton wool around it to keep the wasps from escaping. Only when the wasps walked for at least 5 seconds we used the observation for inclusion in the calculation of the walking speed. Walking speed was recorded using a video camera (Panasonic ${ }^{\circledR}$ GGTV), a video recorder (Panasonic ${ }^{\circledR}$ AG-6200) and colour video monitor (Panasonic ${ }^{\circledR}$ TC $1470-y$ ) connected to a computer. Video tracking and motion analysis were done using the programme Ethovison (version 1.7 Noldus Information Technology). The experimental arena was illuminated from the underside using a circular fluorescent tube separated from the arena by a $1 \mathrm{~cm}$ thick plexiglass plate to avoid heat build-up. For each treatment (infected and cured wasps) thirty replications were done and each female was used only once. A completely random design was used to analyse the data. The data were submitted to analysis of variance and the means compared using the Tukey test $(\mathrm{P} \leq 0.05)$.

\subsection{Behavioural components}

Trichogramma behaviour was studied in a climate room at $25{ }^{\circ} \mathrm{C}$. Wasps were released in an arena containing twenty-five Mamestra brassicae L., 1758 eggs that were placed in a square grid at a distance of $0.7 \mathrm{~mm}$ apart from each other. Twenty replications of infected and cured females were analysed. Wasp behaviour was recorded for the following components: 1) Host contact (=the host egg is touched by the wasp's antennae); 2) Host drumming (=the female wasp drums on the host egg in a standing position or while walking); 3) Turning $360^{\circ}$ (=in general, after the female wasp encounter the host egg circular movements indicate acceptance for oviposition); 4) Drilling + ovipositing position (=females starts ovipositor penetration and adopt an oviposition posture); 5) Host feeding (=the wasp feeds on the host egg through a hole made by the ovipositor); 6) Walking while drumming (=the wasp walks and drums between a previous host egg encounter and the subsequent one); 7) Standing still while drumming (=while stopped the wasp drums the antennae); 8) Standing still (=the wasp stands still on the host egg or arena, sometimes moving the antennae); 9) Preening (=the wasp in standing position usually starts preening body parts such as wings, legs, thorax, antennae etc.). Using the same female wasps (infected and uninfected), additional observations were made by 
measuring the mean number of host eggs parasitised per female, the total number of offspring per female and the offspring sex ratio. These observations were obtained from the parasitised host eggs during the thirty min. experiment. For the evaluation of Trichogramma behaviour a thirty min. observation (experimental unit) was made. The duration of each behaviour component was measured in seconds. Behaviour records started with the first host contact using a video cassette recorder (Panasonic $^{\circledR}$ AG-6200), a colour monitor (Sony ${ }^{\circledR}$ 20" Model No. PVM-2010QM) and a CCD Camera (Model CC-36) connected to a microscope (Zeiss ${ }^{\circledR}$ ). A completely random design was used to analyse the data. The data were submitted to analysis of variance $(\mathrm{P} \leq 0.05)$.

\section{Results}

\subsection{Wolbachia treatment with antibiotic}

After the infected females were fed on honey plus antibiotic in the first generation, male wasps were produced from the third day of oviposition onwards. The cured T. atopovirilia females turned permanently to arrhenotoky from thelytoky after the third generation of antibiotic treatment and that condition was confirmed using PCR and Wolbachia DNA amplification was not detected any longer.

\subsection{Walking activity}

Results of the mean walking activity are shown in Table 1 and 2. The temperature strongly affected the walking activity of $T$. atopovirilia and differences were highly significant $(\mathrm{P} \leq 0.01)$. The higher the temperature, the higher the walking activity. Mean walking activity of infected and cured females wasps during the four days of experiment are shown in Figures 1 and 2. The daily walking activity patterns were similar for the infected and cured females at each of the temperatures studied. Walking activity was high the whole day at $25{ }^{\circ} \mathrm{C}$. At $20{ }^{\circ} \mathrm{C}$, walking activity was higher during the second part of the day. Studying T. brassicae Suverkropp et al. (2001) found the opposite pattern with a higher activity at the first part of the day. During the first two days of the experiment the mean walking activity was lower than during the subsequent ones. At $15{ }^{\circ} \mathrm{C}$, the female wasps were only active at the end of the period reaching maximum values below 0.4 . The highest mean walking activity was observed on the $4^{\text {th }}$ day of the experiment. Walking activity was not different with respect to female reproductive mode. Infected and cured T. atopovirilia females responded similarly on all four days and mean walking activity was highest on the last day of the experiment (Table 2).

\subsection{Walking speed}

The mean hind tibia length of infected $(0.148 \pm$ $0.004 \mathrm{~mm})$ and cured $(0.146 \pm 0.005 \mathrm{~mm})$ T. atopovirilia did not differ statistically ( $T$-test; $\mathrm{P} \leq 0.05)$. Walking speed in Trichogramma females was not influenced by their infection status (Table 2).

\subsection{Behavioural components}

In all the traits we studied no statistical difference was found between infected and cured females (Table 3). Host contact, host drumming, drilling + ovipositing position and walking while drumming were the most common behavioural components observed during the thirty min. experiment. Trichogramma wasps spent most of the time on drilling + ovipositing $(67 \%)$ followed by host drumming (16\%) and walking while drumming (14\%). Only $3 \%$ of the total time was spent on other behaviours (host feeding, standing still while drumming, standing still and preening). Host feeding was a rare event be-

Table 1. Mean walking activity of T. atopovirilia at different temperatures.

\begin{tabular}{ccccc}
\hline \multirow{2}{*}{$\begin{array}{c}\text { Temperature } \\
\left({ }^{\circ} \mathbf{C}\right)\end{array}$} & $\mathbf{1}^{\text {st }}$ & $\mathbf{2}^{\text {nd }}$ & $\mathbf{3}^{\text {rd }}$ & $\mathbf{4}^{\text {th }}$ \\
\cline { 2 - 5 } 25 & $0.9194 \pm 0.0127^{2, a}$ & $0.9281 \pm 0.0114^{\mathrm{a}}$ & $0.9288 \pm 0.0076^{\mathrm{a}}$ & $0.9275 \pm 0.0087^{\mathrm{a}}$ \\
20 & $0.1813 \pm 0.0139^{\mathrm{b}}$ & $0.3694 \pm 0.0185^{\mathrm{b}}$ & $0.5575 \pm 0.0178^{\mathrm{b}}$ & $0.5906 \pm 0.0170^{\mathrm{b}}$ \\
15 & $0.0006 \pm 0.0006^{\mathrm{c}}$ & $0.0150 \pm 0.0034^{\mathrm{c}}$ & $0.0269 \pm 0.0050^{\mathrm{c}}$ & $0.0638 \pm 0.0095^{\mathrm{c}}$ \\
\hline
\end{tabular}

${ }^{1}$ Means followed by the same letter are no significantly different by Tukey test $(\mathrm{P} \leq 0.01)$ of $\sqrt{(\mathrm{x}+1)}$-transformed data; ${ }^{2}$ Original Mean \pm SE.

Table 2. Mean walking activity and speed of T. atopovirilia.

\begin{tabular}{|c|c|c|c|c|c|}
\hline \multirow{2}{*}{$\begin{array}{c}\text { Reproduction } \\
\text { mode }\end{array}$} & \multicolumn{4}{|c|}{ Walking activity ${ }^{1 / d a y}$} & \multirow{2}{*}{$\begin{array}{l}\text { Walking speed } \\
\qquad(\mathrm{cm} / \mathrm{s})^{2}\end{array}$} \\
\hline & $1^{\text {st }}$ & $2^{\text {nd }}$ & $3^{\text {rd }}$ & $4^{\text {th }}$ & \\
\hline Thelytoky & $0.38 \pm 0.04^{3, \mathrm{a}}$ & $0.44 \pm 0.04^{\mathrm{a}}$ & $0.52 \pm 0.04^{\mathrm{a}}$ & $0.54 \pm 0.03^{\mathrm{a}}$ & $0.35 \pm 0.02^{\mathrm{a}}$ \\
\hline Arrhenotoky & $0.35 \pm 0.04 b$ & $0.43 \pm 0.04^{\mathrm{a}}$ & $0.49 \pm 0.04^{\mathrm{a}}$ & $0.52 \pm 0.03^{\mathrm{a}}$ & $0.34 \pm 0.03^{\mathrm{a}}$ \\
\hline
\end{tabular}

${ }^{1,2}$ Means followed by the same letter are no significantly different by Tukey test $(\mathrm{P} \leq 0.05)$ of $\sqrt{(\mathrm{x}+1)}$-transformed data. ${ }^{3}$ Original Mean \pm SE. 

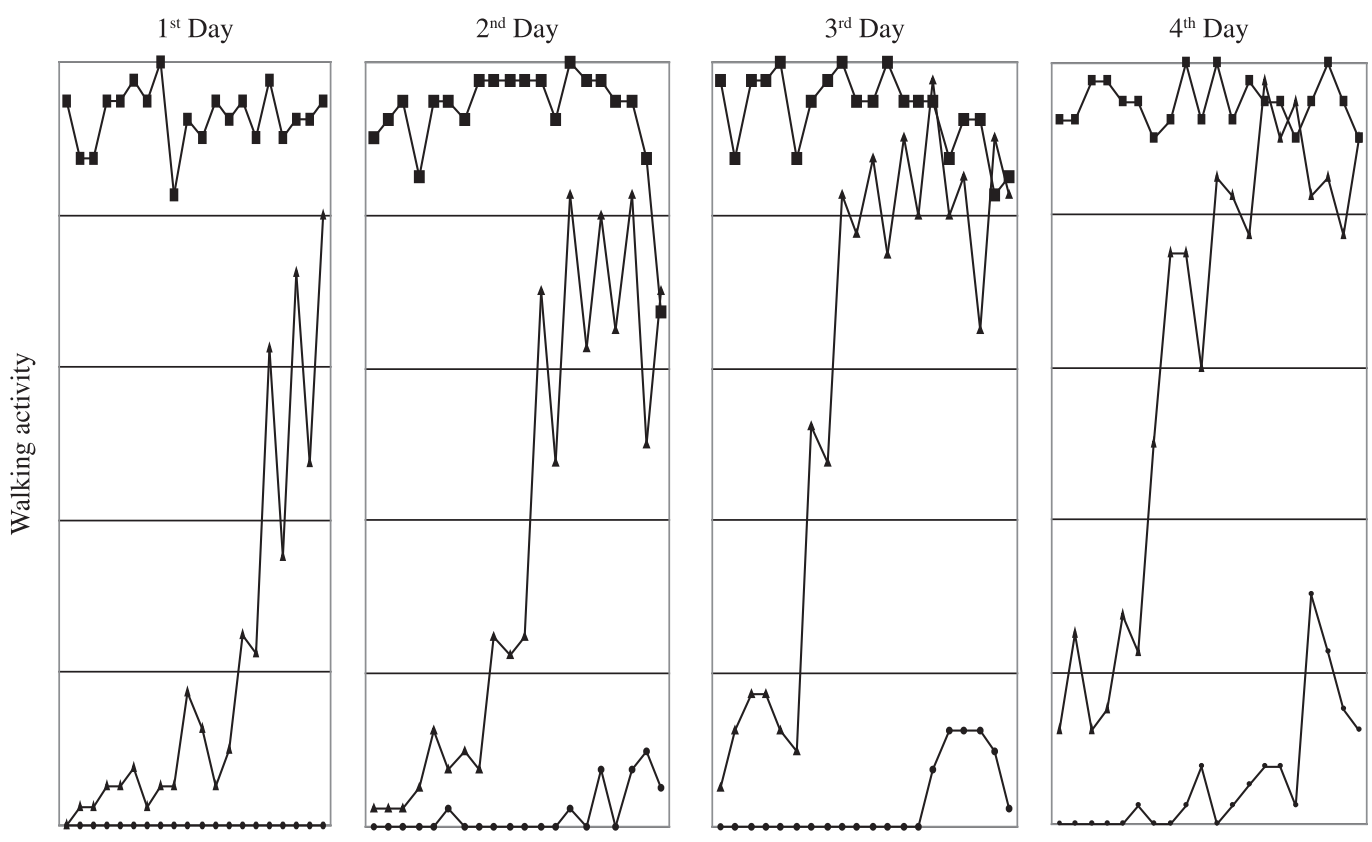

Time (hours)

$\longrightarrow 25^{\circ} \mathrm{C} \longrightarrow 20^{\circ} \mathrm{C} \longrightarrow 15^{\circ} \mathrm{C}$

Figure 1. Mean walking activity of infected T. atopovirilia females during 4 days at three temperatures.
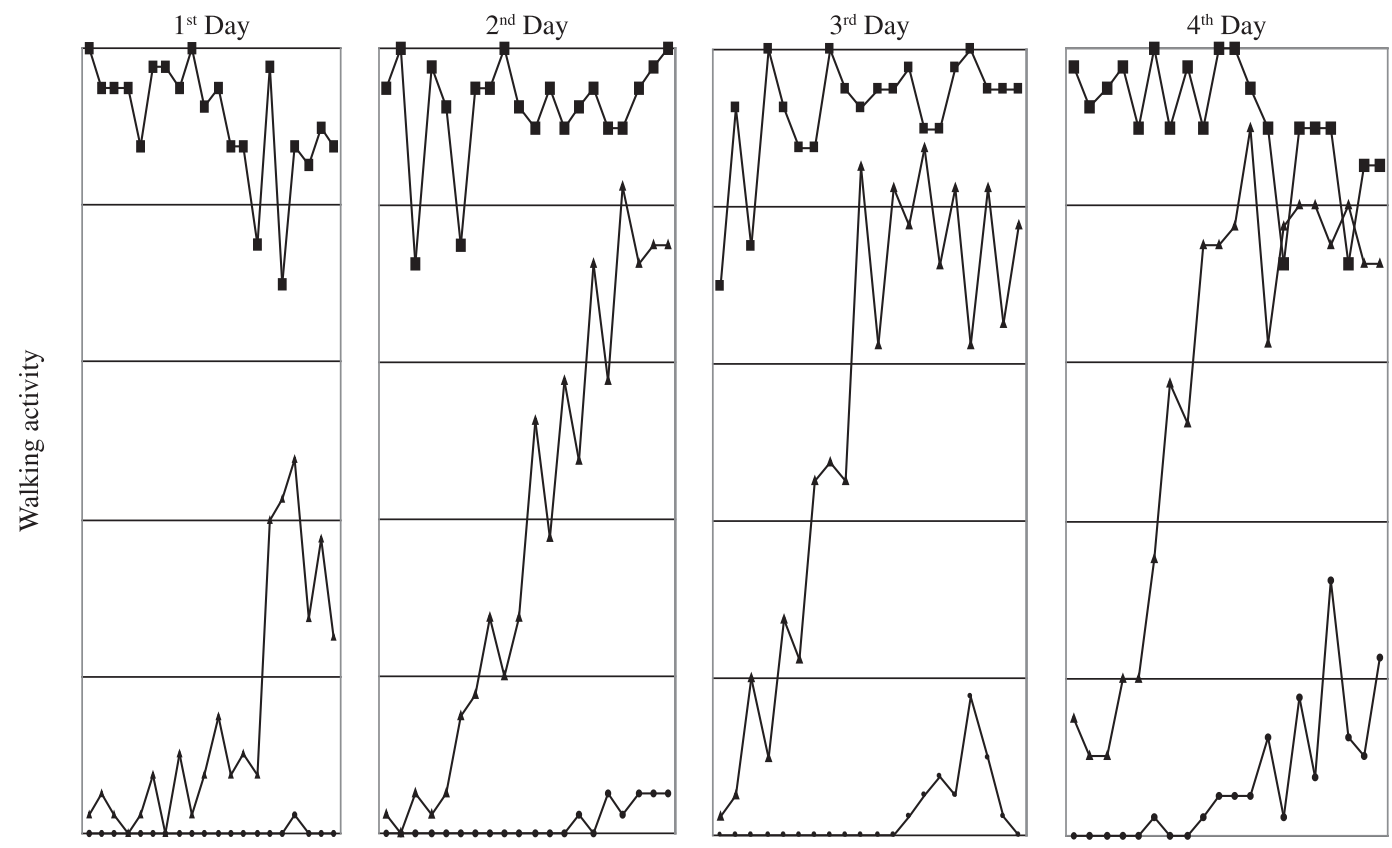

Time (hours)

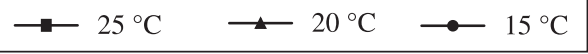

Figure 2. Mean walking activity of cured $T$. atopovirilia females during 4 days at three temperatures. 
Table 3. Mean of the duration time $(s)^{1}$ of the behavioural components and biological parameters of infected and cured T. atopovirila.

\begin{tabular}{|c|c|c|c|}
\hline \multirow[t]{2}{*}{ Behaviour/biological } & \multicolumn{2}{|c|}{ Reproduction mode } & \multirow[t]{2}{*}{ F-test } \\
\hline & Thelytoky & Arrhenotoky & \\
\hline Total host drumming ${ }^{1}$ & $284.50 \pm 9.43$ & $284.75 \pm 30.73$ & $0.00^{\text {ns }}$ \\
\hline Host drumming/host egg & $26.75 \pm 1.11$ & $29.50 \pm 4.48$ & $0.35^{\text {ns }}$ \\
\hline Total drilling + ovipositing position ${ }^{1}$ & $1,240.25 \pm 28.35$ & $1,185.50 \pm 18.70$ & $2.60^{\mathrm{ns}}$ \\
\hline Drilling + ovipositing position/host egg & $124.50 \pm 4.99$ & $122.50 \pm 5.87$ & $0.07^{\mathrm{ns}}$ \\
\hline Total walking while drumming ${ }^{1}$ & $210.75 \pm 31.85$ & $282.25 \pm 34.81$ & $2.30^{\mathrm{ns}}$ \\
\hline Number of parasitised host eggs ${ }^{1}$ & $9.15 \pm 0.25$ & $8.95 \pm 0.30$ & $0.26^{\mathrm{ns}}$ \\
\hline Total number of offspring ${ }^{1}$ & $21.60 \pm 0.81$ & $20.50 \pm 0.77$ & $0.98^{\mathrm{ns}}$ \\
\hline Sex ratio & 1.00 & 0.65 & - \\
\hline
\end{tabular}

${ }^{1}$ Thirty minutes evaluation; ${ }^{\text {ns }}$ Means do not differ significantly by F-test $(\mathrm{P} \leq 0.05) ;{ }^{2}$ Mean $\pm \mathrm{SE}$.

cause the female wasps fed immediately on honey after emergence one day before the experiment started. Thelytokous and arrhenotokous females were equally efficient in the number of host eggs parasitised and in the number of offspring produced (Table 3 ).

\section{Discussion}

The use of parthenogenetic forms and their potential advantages for biological control of insect pests have been suggested (Aeschlimann, 1990; Stouthamer, 1993), even though the infection can have negative effects on some life history traits (Stouthamer and Luck, 1993; Stouthamer et al., 1994; Horjus and Stouthamer, 1995; Hoogenboom et al., 1998).

Our results showed that Wolbachia infection did not negatively affect $T$. atopovirilia walking activity, walking speed and behaviour. The situation where thelytokous females coexist with arrhenotokous ones is known as a mixed population. Infected females are able to mate and produce daughters sexually. The species used in this study (T. atopovirilia) probably originated from a fixed population. All females in the population are infected. Our results are consistent with the theory that the reduction of the negative impact of the symbiont on its host should be found when the population becomes fixed for infection (Meer, 1999).

Statistical differences were not observed between infected and cured female wasps in the walking activity. A higher walking activity was found in T. brassicae (Suverkropp et al. 2001) at low temperature than in T. atopovirilia. This fact can be explained because the latter species is well adapted to tropical climate and consequently suffers at temperatures below $20{ }^{\circ} \mathrm{C}$. $T$. brassicae is more adapted to temperate conditions. Individual variability in walking activity was higher at $20{ }^{\circ} \mathrm{C}$ (Figure 1 and 2). At $15^{\circ} \mathrm{C}$ females showed less variability, although they were less active for both infected and cured Trichogramma wasps.

The mean walking speed obtained here was similar to that observed by Suverkropp et al. (2001) for T. brassicae at $20^{\circ} \mathrm{C}$. The walking speed results confirm that infected females of T. atopovirilia are not affected in this trait by their Wolbachia infection. Host size has been the most frequent metric parameter used in bioassays, although it has no direct relation to fitness. It is used in combination to other fitness proxies such as fecundity, mating ability, longevity, etc (Roitberg et al., 2001). Stouthamer and Luck (1993), Wang and Smith (1996) and Hoogenboom et al. (1998) showed that arrhenotokous lines produced significantly more daughters than their thelytokous counterparts when allowed to lay eggs for their whole life, but longevity was similar for both infected and uninfected females.

In the behaviour experiment, Trichogramma wasps previously fed on honey were able to easily find the host eggs individually distributed at a $0.7 \mathrm{~mm}$ distance from each other. The Trichogramma females when released in the experimental arena immediately started searching for host eggs. After encountering a host egg the Trichogramma wasp examined the egg by antennal drumming contact, followed by the drilling through the eggshell with the ovipositor. Depending on the size of the host, one or more eggs are laid (Salt, 1935; Klomp and Teerink, 1962; Schmidt and Smith, 1985a, b). Pak (1998) mentioned contact, drumming, drilling, ovipositing and host feeding as the major phases of the parasitisation behaviour of a Trichogramma female. On the whole, T. atopovirilia females laid 3-4 eggs per host egg in the first host egg encountered. After withdrawal of the ovipositor, the wasps may feed on the host cytoplasm oozing from the eggshell puncture.

After release of the T. atopovirilia wasps in the experimental arena the females were rarely observed host feeding, standing still or preening. Sometimes when the female wasps were in a drilling activity and preparing for the oviposition step, they would stop and start searching for another egg. Van Dijken et al., (1986) showed that parasitoids might reject the host egg during any phase of the examination or parasitism process and also after a brief initial contact without drumming or visually from a short distance. The ability of the parasitoid in host discrimination is not acquired until a female has had an ovi- 
position experience with an unparasitised host (Klomp et al., 1980). Trichogramma are able to discriminate between parasitised and unparasitised hosts (Lenteren et al., 1978; Lenteren, 1981). In our experiments the females would sometimes encounter the parasitised host egg two or three times, but these hosts were never superparastised. The ability of infected females in producing more daughters when the host eggs availability is limited (Stouthamer and Luck, 1993) may help control an insect pest. When host eggs are limited the negative effect of Wolbachia infection on the total offspring production will not be important, most females will never lay all of their eggs. For T. atopovirilia the host egg availability was similar for both infected and cured female wasps and no difference in their searching ability was found indicating that the Wolbachia infection does not influence these traits.

From our results we can conclude that the infected T. atopovirilia appears more suitable for biological control programmes. However, further studies should be performed on the parasitoid to determine how well the wasps can be mass reared, and how a quality control programme can be instituted (Smith, 1996).

Acknowledgements - We thank Américo Ciociola Jr. (EPAMIG, Brazil) who sent the Trichogramma atopovirilia species used in this research. This research was supported by Embrapa (Brazilian Agricultural Research Corporation)/PRODETAB and the graduate school Production Ecology \& Resource Conservation of the Netherlands (R.P.A).

\section{References}

AESCHLIMANN, JRP., 1990. Simultaneous occurrence of thelytoky and bisexuality in hymenopteran species, and its implications for the biological control of species. Entomophaga, vol. 35, no. 1, p. 3-5.

BIEVER, KD., 1972. Effect of temperatures on the rate of search by Trichogramma and its potential application in field releases. Environmental Entomololgy, vol. 1, no. 2, p. 194-197.

BIGLER, F., 1994. Quality control in Trichogramma production. In WAJNBERG, E. and HASSAN, SA. (Eds.). Biological Control with Egg Parasitoids. Wallingford: CAB International. p. 93-111.

BOLDT, PE., 1974. Temperature, humidity, and host: effect on rate of search of Trichogramma evanescens and T. minutum Auctt. (not Riley, 1871). Annals of the Entomologycal Society of America, vol. 67, no. 4, p. 706-708.

BRAIG, HR., ZHOU, W., DOBSON, S. and O'NEILL, SL., 1998. Cloning and characterization of a gene encoding the major surface protein of the bacterial ensosymbiont Wolbachia pipientis. Journal of Bacteriology, vol. 180, no. 9, p. 2373-2378.

BURBUTIS, PP., CURL, GD. and DAVIS, CP., 1977. Host searching behavior by Trichogramma nubilale on corn. Environmental Entomology, vol. 6, no. 3, p. 400-402.

CERUTTI, F. and BIGLER, F., 1991. Methods for quality evaluation of Trichogramma evanescens used against the European Corn Borer. In BIGLER, F. (Ed.). Proceedings of the 5 Workshop of the IOBC Global Working Group "Quality Control of Mass Reared Arthropods", Março 25-28. Switzerland: International Organization for Biological Control of Noxious Animals and Plants Zurich. p. 119-126.

CERUTTI, F. and BIGLER, F., 1995. Quality assessment of Trichogramma brassicae in the laboratory. Entomologia Experimentalis et Applicata, vol. 75, no. 1, p. 19-26.

CIOCIOLA Jr., AC., ALMEIDA, RP., ZUCCHI, RA. and STOUTHAMER, R., 2001a. Detecção de Wolbachia em uma população telítoca de Trichogramma atopovirilia Oatman and Platner (Hymenoptera: Trichogrammatidae) via PCR com o Primer Específico wsp. Neotropical Entomology, vol. 30, no. 3, p. 489-491.

Van DIJKEN, MJ., KOLE, M., Van LENTEREN, JC. and BRAND, AM., 1986. Host preference studies with Trichogramma evanescens Westwood (Hym.: Trichogrammatidae) for Mamestra Brassicae, Pieris Brassica and Pieris rapae. Journal of Applied Entomology, vol. 101, p. 64-85.

DROST, YC., QIU, YT., POSTHUMA-DOODEMAN, CJAM. and Van LENTEREN, JC., 2000. Comparison of searching starategies of five parasitoid species of Bemisia argentifolli Bellow and Perring (Hom., Aleyrodidae). Journal of Applied Entomology, vol. 124, p. 105-112.

GIRIN, C. and BOULÉTREAU, M., 1995. Microorganism-associated variation in host infestation efficiency in a parasitoid wasp Trichogramma bourarachae (Hymenoptera: Trichogrammatidae). Celular and Molecular Life Sciences, vol. 51, no. 4, p. 398-401.

GREENBERG, S., 1991.Evolution techniques for Trichogramma quality. In BIGLER, F. (Ed.). Proceedings of the 5 Workshop of the IOBC Global Working Group "Quality Control of Mass Reared Arthropods", Março 25-28. Switzerland: International Organization for Biological Control of Noxious Animals and Plants Zurich. p. 138-145.

HOOGENBOOM, A., SILVA, IMMS., Van MEER, MMM., ROSKAM, MM. and STOUTHAMER, R., 1998. Quality assessments of Wolbachia infected versus non infected lines of Trichogramma deion. Proceedings of the Section Experimental and Applied Entomology, vol. 9, p. 99-104.

HORJUS, M. and STOUTHAMER, R., 1995. Does infection with thelytoky-causing Wolbachia in pre-adult and adult life stages influence the adult fecundity of Trichogramma deion and Muscidifurax uniraptor? Proceedings of the Section Experimental and Applied Entomology, vol. 6, p. 35-40.

KAZMER, DJ. and LUCK, RF., 1995. Field test of the size-fitness in the egg parasitoid Trichogramma pretiosum. Ecology, vol. 76, no. 2, p. 412-425.

KLOMP, H., TEERINK, BJ. and MA, WC., 1979. Discrimination between parasitized and unparasitized hosts in the egg parasite Trichogramma embryophagum (Hym.: Trichogrammatidae): a matter of learning and forgetting. Netherlands Journal of Zoology, vol. 30, no. 2, p. 254-277.

KLOMP, H. and TEERINK, BJ., 1962. Host selection and number of eggs per oviposition in the egg-parasite Trichogramma embryophagum Htg. Nature, vol. 195, p. 1020-1021.

KOT, J., 1979. Analysis of factors affecting the phytophage reduction by Trichogramma Westw. species. Polish Ecological Studies, vol. 5, p. 5-59. 
Van ENTEREN, JC., 1981. Host discrimination by parasitoids. In NORLUND, DA., JONES, RL. and LEWIS, WJ. (Eds.). Semiochemichal, their role in pest control. New York: Wiley. p. 153-179.

1991. Quality control of natural enemies: hope or illusion. In BIGLER, F. (Ed.). Proceedings of the 5 Workshop of the IOBC Global Working Group "Quality Control of Mass Reared Arthropods", Março 25-28. Switzerland: International Organization for Biological Control of Noxious Animals and Plants Zurich. p. 1-15.

2000. Measures of success in biological control of arthropods by augmentation of natural enemies. In GURR, G. and WRATTEN, S. (Eds.). Measures of Success in Biological Control. Dordrecht: Kluwer Academic Publishers. p. 77-103.

Van LENTEREN, JC., BAKKER, K. and Van ALPHEN, JJM., 1978. How to analyze host discrimination? Ecological Entomology, vol. 3, p. 71-75.

Van LENTEREN, JC. and MANZAROLI, G., 1999. Evaluation and use of predators and parasitoids for biological control of pests in greenhouses. In ALBAJES, R., GULLINO, ML., Van LENTEREN, JC. and ELAD, Y. (Eds.). Integrated Pest and Disease Management in Greenhouse Crops. Dordrecht: Kluwer Academic Publishers. p. 183-201.

Van LENTEREN, JC., NELL, HW. and Van der LELIE, LAS., 1980. The parasite-host relationship between Encarsia formosa (Hymenoptera: aphelinidae) and Trialeurodes vaporariorum (Homoptera: Aleyrodidae). IV Ovipositon behaviour of the parasite, with aspects of the host selection, host discrimination and host feeding. Journal of Applied Entomology, vol. 89, p. $442-454$.

Van MEER, MMM., 1999. Phylogeny and host-symbiont interactions of thelytokous inducing Wolbachia in Hymenoptera. The Netherlands: Wageningen University. 118 p. [Tese de Doutorado].

PAK, GA., 1988. Selection of Trichogramma for inundative biological control. The Netherlands: Wageningen University. 224 p. [Tese de Doutorado].

POMPANON, F., FOUILLET, P. and BOULETREAU, M., 1994. Locomotor behaviour in females of two Trichogramma species: description and genetic variability. Norwegian Journal of Agricultural Sciencies, Supplement, no. 16, p. 185-190.

ROERMUND, HJW. Van, 1995. Understanding biological control of greenhouse whitefly with the parasitoid Encarsia Formosa. The Netherlands: Wageningen University. 243 p. [Tese de Doutorado].

ROITBERG, BD., BOIVIN, G. and VET, LEM., 2001. Fitness, parasitoids, and biological control: an opinion. Canadian Entomologist, vol. 133, no. 3, p. 429-438.

ROMEIS, J., SHANOWER, TG. and ZEBITZ, CPW., 1998. Physical and chemical plant characters inhibiting the searching behaviour of Trichogramma chilonis. Entomologia Experimentalis et Applicata, vol. 87, no. 3, p. 275-284.

SALT, G., 1935. Experimental studies in insect parasitism. III Host selection. Proceedings of The Royal Society of London Series B Biological Sciences, vol. 117, p. 413-435.

SCHMIDT, JM. and SMITH, JJB., 1985a. Host volume measurement by the parasitoid wasp Trichogramma minutum: the roles of curvature and surface area. Entomololgia Experimentalis et Applicata, vol. 39, no. 3. p. 213-221. 1985b. The mechanism by which the parasitoid was Trichogramma minutum responds to host clusters. Entomologia Experimentalis et Applicata, vol. 39, no. 3, p. 287-294.

SILVA, IMMS., Van MEER, MMM., ROSKAM, MM., HOOGENBOOM, A., GORT, G. and STOUTHAMER, R., 2000. Biological control potential of Wolbachia infected (unisexual) versus uninfected (sexual) wasps: laboratory and greenhouse evaluation of Trichogramma cordubensis and T. deion strains. Biocontrol Science and Technology, vol. 10, no. 3 , p. 223-238.

SMITH, SM., 1996. Biological control with Trichogramma: advances, successes, and potential of their use. Annual Review of Entomololgy, vol. 41, p. 375-406.

STOUTHAMER, R., 1993. The use of sexual versus asexual wasps in biological control. Entomophaga, vol. 38, no. 1, p. 3-6.

STOUTHAMER, R., BREEUWER, JAJ. and HURST, GDD., 1999. Wolbachia pipientis: microbial manipulator of arthropod reproduction. Annual Review of Microbiology, vol. 53, p. 71-102.

STOUTHAMER R., LUKO, S. and MAK, F., 1994. Influence of parthenogenesis Wolbachia on host fitness. Norwegian Journal of Agricultural Sciences, Supplement no.16, p. 117-122.

STOUTHAMER, R. and LUCK, RF., 1993. Influence of microbe-associated parthenogenesis on the fecundity of Trichogramma deion and T. pretiosum. Entomologia Experimentalis et Applicata, vol. 67, no. 2, p. 183-192.

STOUTHAMER, R., LUCK, RF. and HAMILTON, WD., 1990. Antibiotics cause parthenogenetic Trichogramma to revert to sex. Proceedings of the National Academy of Sciences, vol. 87, no. 7 , p. 2424-2427.

SUVERKROPP, BP., 1994. Landing of Trichogramma brassicae Bezdenko (Hymenoptera: Trichogrammatidae) on maize plants. Norwegian Journal of Agricultural Sciencies, Supplement no.16, p. 243-254

SUVERKROPP, BP., BIGLER, F. and Van LENTEREN, JC., 2001. Temperature influences walking speed and walking activity of Trichogramma brassicae (Hym., Trichogrammatidae). Journal of Applied Entomology, vol. 125, p. 303-307.

TAGAMI, Y., MIURA, K. and STOUTHAMER, R., 2002. How does infection with parthenogenesis-inducing Wolbachia reduce the fitness of Trichogramma? Journal of Invertebrate Pathology, vol. 76, p. 267-271.

VAVRE, F., GIRIN, C. and BOULÉTREAU, M., 1999. Phylogenetic status of a fecundity-enhancing Wolbachia that does not induce thelytoky in Trichogramma. Insect Molecular Biology, vol. 8, no. 1, p. 67-72.

WADE, MJ. and CHANG, NW., 1995. Increased male fertility in Tribolium confusum beetles after infection with the intracellular parasite. Wolbachia. Nature, vol. 373, p. 72-74.

WANG, Z. and SMITH, SM., 1996. Phenotypic differences between thelytokous and arrhenotokous Trichogramma minutum from Zeiraphera Canadensis. Entomologia Experimentalis et Applicata, vol. 78, no. 3, p. 315-323. 